\title{
Corporate Social Responsibility and Firm Performance: A Review of Literatures
}

\author{
Barnabas Gogo Pepple ${ }^{1}$, Boniface Uzoma Emenike ${ }^{1}$, Kingsley Ala Wilcox ${ }^{2}$ \\ ${ }^{1}$ Department of Petroleum Marketing and Business Studies, Federal Polytechnic of Oil and Gas Bonny, Port Harcourt, Nigeria \\ ${ }^{2}$ Mathematics Department, RA International School Bonny-Island, Port Harcourt, Nigeria
}

\section{Email address:}

barnpeppleg@gmail.com (B. G. Pepple), bonmenyke@gmail.com (B. U. Emenike), kingeverest510@gmail.com (K. A. Wilcox)

\section{To cite this article:}

Barnabas Gogo Pepple, Boniface Uzoma Emenike, Kingsley Ala Wilcox. Corporate Social Responsibility and Firm Performance: A Review of Literatures. International Journal of Business and Economics Research. Vol. 10, No. 4, 2021, pp. 110-116.

doi: 10.11648/j.ijber.20211004.11

Received: June 16, 2021; Accepted: June 29, 2021; Published: July 13, 2021

\begin{abstract}
The importance of Corporate Social Responsibility cannot be overemphasized, and good Corporate Social Responsibility will constitute good relationship for both the implementing business and its stakeholders- such as customers, community, suppliers, government etc., of such business. The idea behind Corporate Social Responsibility is largely misunderstood by many to deal with only large organizations and multinational. However, even small businesses can in their own little ways be socially responsible. For instance, both large and small businesses do employ workers, operate in a community, impact on the environment on which they operate and are expected to pay taxes to the government of their nation. Consequently, by employing worker, the business is expected to maintain and services such workers in other to retain them and by operating in a community, the business owe such community among other things healthy goods and contributions to societal activities. Therefore, it doesn't necessarily mean that a business must be large before Corporate Social Responsibility can be implemented. All the aforementioned activities are all inclusive in the Corporate Social Responsibility list. This study considered the meaning of Corporate Social Responsibility from varying authorities, reviewed literatures on previous studiesspecifically those with positive relationship, negative relationship, mixed relationship and modest relationship. Following the robust literature review, gaps in studies were identified and consequently, need for further studies. Finally, conclusion was made and recommendations suggested.
\end{abstract}

Keywords: Corporate Social Responsibility, Firm Performance, Community, Customers and Suppliers

\section{Introduction}

This study reviewed literatures on the impact of Corporate Social Responsibility (CSR) and Firm Performance (FP). The increasing sophistication and the impact of firm stakeholders (customers, communities, suppliers, employees etc.) activities have caused firms to incorporate these stakeholders in their policies and to be responsive to them as their activities could have bearing on the performance of the firm. The aforementioned scenario gave birth to the concept of CSR. CSR as a discipline in management emerged in the 1950 s, in US [1]. In terms of definition, there has been no homogeneity in defining CSR [2] and as such, it becomes difficult to correctly provide generally accepted definition of CSR [3], thereby making the definition of CSR ambiguous [4], and Such absence of a specific and widely agreed definition makes CRS vulnerable to confliction interpretation by stakeholders [5]. Notwithstanding, authorities have provided insight to understanding its meaning.

CSR is a business obligation to conduct the affairs of the enterprise to maintain an equitable and workable balance among the claims of the directly interested groups, a homogenous balance among stockholders, employees' customers' and public at large [6]. European Commission [7] viewed CSR as a concept whereby companies integrate social and environmental concerns in their interaction with their stakeholders on a voluntary basis. According to [8], corporate social responsibility is the responsibility of an organization for the impact of its decisions and activities on the society and environment, through transparent and ethical behavior that; (a) contributes to sustainable development, health and the welfare of society; (b) takes into account the expectations 
of stakeholders; (c) is in compliance with applicable laws and consistent with international norms and behavior; and (d) is integrated through the organization and practiced in its relationships. In the above definitions of corporate social responsibility, they all suggested the need for firms to show concern to their stakeholders. Drawing from these, [9] concluded that corporate social responsibility began with focus on the role of business leaders: particularly, on how they managed their companies with a view to society and how they gave back to their local communities. However, as noted by [10] the human senses- sight, hearing, touch, taste, smell and the sensing of internal bodily signals or 'kinastlesia', each consist of specialist nerves that respond to specific form of energy, such as light, sound, pressure and temperature change. So also do the elements of corporate social responsibility have their respective nerves through which they respond to organization concern for them and through which the organization must extend their concern. Therefore, it implies that the relationship between employee and firm is different from the relationship between customers, suppliers, communities and the firm. Hence, the firm must not apply the same methodology it used while dealing with its employees on its customers and as such for the firm to be successful in implementing its corporate social responsibility, it must identify, understand and deal with each elements of corporate social responsibility from its nerves. As concluded by [11] at greater risk are firms that fail to carefully monitor their customers, employees, stockholders and suppliers. On the other hand, firm performance also referred to as corporate performance, as a concept has had no consensus among authorities with respect to its definition and as such has no generally accepted definition. However, researchers have attempted to proffer deferent definition from deferent perspective. In this study, for the purpose of congruency and uniformity, the concept shall be used and addressed as firm performance. According to [12] the definition of firm performance varies from one to another. Hence, [13] see firm performance as measure of percentage of sales resulting from new products, capital employed, profitability and return on assets (ROA). [14] defined firm performance as how organization financial resources are judiciously put to use to achieve the corporate objectives of the organization. In this definition, though it sounded from the financial perspective, it encompasses the entire operational activities of the organization in terms of not just effectiveness but also efficiency. Finally, [15] concluded that the performance of a firm can take the good or poor perspective. Having knowledge of the concepts of, corporate social responsibility and firm performance, now pave way to treat it as a subject (which invariably, is the essence of this study).

\subsection{Aims and Objectives}

This study is carried out to review literatures on the relationship between corporate social responsibility (CSR) and firm performance (FP). While in recent years, this subject has been an area of concern among researchers, most of these studies were to test the relationship between the subject matter. The current study however, will review prior studies carried out on the subject matter, to assemble results of empirical studies, contribute to knowledge in general and bridge gap in study

In the next sections, previous literatures will be reviewed and consequently, gaps in literature will be closed. The aforementioned will be followed by conclusion and recommendations, while limitations of the study and suggestions for further studies will end the study

\subsection{Significance of the Study}

This study was carried out to ascertain the relationship between corporate social responsibility and firm performance, with emphasis on review of literatures. Following the increasing number of researchers and the quest of business practitioners to explore avenues that will contribute to their profit profile, this study assembled results of previous studies and stressed the need for businesses (large and small) to embark on corporate social responsibility. Therefore, this study will be significant to researchers who will have access to results of previous studies which will aid their studies. Further, this study will be of significance to business practitioners who will understand that discharging corporate social responsibility, could bring about improved firm performance.

\section{Literature Review}

While there is yet no consensus among practitioners, academia and researchers to the meaning of corporate social responsibility, [16] put it thus: 'One of the challenges, in an area as innovative as CSR, is the difficulty of developing commonly accepted terminology and definition'. However, whilst the words may be different, the components are essentially the same'. The aforementioned promulgation of [16] clearly depict the fact that while there is yet no generally accepted definition of corporate social responsibility, there are numerous authorities that have created the platform to understanding the concept of corporate social responsibility. However, while these definitions are from different perspectives they essentially mean the same thing, the author concluded.

Furthermore, there has been in the last three decades increased interest among researchers on the subject of corporate social responsibility and firm performance, [17], while there is no homogeneity yet among researchers, this has left some scholars of corporate social responsibility to question the existence of clear motivation for firms to be socially responsive [18]. The varying findings among researchers can largely be attributed to the data set, research area and population, and the method employed to carry out the study. In this section, prior studies of the subject (Corporate Social Responsibility and Firm Performance) will be extensively reviewed. Owing to the nature of the subject, to achieve this, Prior studies will be grouped based on their findings, as this is designed to aid critical evaluation and will 
be followed by brief consideration of some of the dimensions of CSR. It is also essential to note that while there are so many dimensions of CSR; researchers have concentrated also on different dimensions thereby making available literature on each of these dimensions limited.

\subsection{Corporate Social Responsibility and Firm Performance with Positive Relationship}

Fasanya O. I. and Onakoya O. B. A [19] carried out study in Nigeria (Cadbury Nig. plc.) in 2013, employing questionnaire for data collection with 187 respondents and this study utilized Chi-square statistical technique to test the relationship between corporate social responsibility and firm performance and the study found a positive relationship between corporate social responsibility and firm performance. That is, the engagement of Cadbury Nigeria plc in corporate social responsibility, leads to increase in its financial performance. However, this study was based on only one company (Cadbury Nigeria plc) and employed questionnaire for data collection. As noted by [20] generalizable justification of single organization might inherently not be possible, though meta-study has found positive relationship between corporate social responsibility and firm performance indicators. In another study, [21] carried out study on the 2007 corporate social responsibility and firm performance of 40 Nigeria companies, employing corporate social responsibility measures (Employee relation, concern for community, and concern for environment) as independent variable measures, return on assets (ROA) and return on equity (ROE) as dependent variable measures. To test the level of relationship between the dependent variable and independent variable, the researchers employed Pearson correlation model and their result showed a positive relationship between corporate social responsibility and firm performance. The analysis of this result showed that each of the independent variable measure (Employee relation, concern for community, and concern for environment) has positive relationship with each of the firm performance measure (return on assets and return on equity). That is, the embarking of these companies on corporate social responsibility, resulted to increase in the financial performance of the companies. Though the result of both [19] and [21] showed a positive result, however, they employed different methods both in data collection with [19] using primary data and [21] using secondary data and in testing the relationship between the variables, [19] used Chi-square while [21] Pearson correlation model. Therefore, these results showed that though the methods adopted and the measures of variable where different, yet it has no effect on the findings. These findings also agree with the findings of [22]. The above studies were carried out in 2012 and 2013 respective and there is need to assemble such literatures that gap in study be identified and further studies encouraged.

Furthermore, [23] studied 150 companies in India between 2005-2009 using regression analysis method and return on assets (ROA) and discover the existence of positive correlation between corporate social responsibility and firm performance. While regression analysis and return on assets (ROA) are widely used phenomena in social science research, there are manipulative possibilities of management on return on assets (ROA) as an accounting generated information which could lead to misleading findings. As noted by [24] high risk tolerant firms may behave differently than low risk tolerant firms in terms of CSR investment because of different levels of risks involved in CSR investment. Furthermore, two separate performance indicators (accounting based and market based) were employed. According to [25], both accounting and market based indicators are financial measures; however they focus on different aspects of financial measure and are subject to particular bias. [26] stated that, accounting information is only historical and gives no indication about the future. Furthermore, within the context of corporate social responsibility (CSR) and firm performance (FP), [27] argued against the use of stock price (market based), that stock price relate only to stockholders that has financial stake in the company while non-financial stakeholders are also subject to corporate social responsibility activity. From the aforementioned, the study of [23], was carried out in 2010 and with the current year of 2021, imply gap in literature and require further study.

Mwangi I. C, et al [28] in Kenya 'between' 2007-2011 carried out study on ten (10) companies to evaluate the nexus between corporate social responsibility (CSR) and financial performance (FP) of firms in the Manufacturing, construction and allied sectors. The independent variable corporate social responsibility was measured through: corporate social responsibility (CSR) score; manufacturing efficiency and capital intensity, while the dependent variable financial performance was measured through ROA. And multiple regression model was used to ascertain the level of relationship between the variables and the findings showed a positive relationship between corporate social responsibility (CSR) and firm performance (FP). This is in congruence with [29] who earlier carried out study also in Kenya and found positive relationship between corporate social responsibility (CSR) and firm performance (FP). However, unlike [28], [29] focused only on the oil industry.

In another study, which only measured financial performance with accounting indicators (return on assets, return on equity, return on sales and net profit margin), [30] carried out study in Iran with a sample of 205 respondent and found a positive relationship between corporate social responsibility and firm performance after measuring corporate social responsibility with: Legal, economic, discretionary and ethical adherence, while testing the relationship employing confirmatory factor analysis (CFA). However, this study only employed accounting measures which is subject to managerial influence and may not aid effective decision making by investors, hence more studies are required to take into account market measures of firm performance.

It is therefore evident from the above review of literatures that more attention was given to the accounting measures of performance than the market measures. Therefore, there is 
need for further studies using either combinations of measures or more of the market measures.

\subsection{Corporate Social Responsibility and Firm Performance with Negative Relationship}

With a selected list of 20 companies from Taiwan stock exchange as extracted from GVM (an independent corporate social responsibility rating company in Taiwan), [31], examined the nexus between measures of corporate social responsibility and stock returns 'between' 2005-2009. Measuring corporate social responsibility (CSR), the researchers grouped the companies into CSR and Non-CSR (that is companies that embark on CSR and the ones that do not invest in CSR) while firm performance (stock return in this context) was measured with both accounting measurers and market-based measure. The reason for this combination (accounting and market-based indicators) was that 'the ultimate goal of a typical firm is to maximize profit while for a typical public company, the goal is to maximize its shareholder's wealth', the researchers stated. And in determining the performance relationship between these CSR and Non-CSR companies, the researchers employed the stochastic dominance (SD) approach. The essence of this approach according to the researchers is that, because it utilizes the whole distribution of returns, the problems that can arise if the assets returns are not normally distributed, is extensively lightened. At the end of the study, a negative relationship was found between measures of corporate social responsibility (CSR) and stock returns (that is firm performance). despite the small sample size of this study, which is not a representation of the population of the companies in the Taiwan stock exchange, the extraction of these companies from an independent corporate social responsibility rating company, implies that these selected companies must have met certain criteria and standard to be included in such independent rating company data-base. And such criteria and standard must have deprived other companies of Taiwan that also invest in corporate social responsibility (CSR) not to be included in the study which could have affected the findings of the study. Furthermore, the use of both accounting measures and market-based measures to measure firm performance (stock return) made it impossible to ascertain the actual effect of each predictor on firm performance in this context. As stated by [20], studies show the existence of difference in the prediction capabilities of both accounting predictors and market-base predictors on firm performance. Hence, while this study was carried out in 2011, there is also need for further study outside the used of independent rating company data.

\subsection{Corporate Social Responsibility and Firm Performance with Mixed Relationship}

With a sample of 157 observers, [32] carried out study in US 'between' 1991-2009 to test the relationship between corporate social responsibility and firm performance in the airline industry. The independent variable (corporate social responsibility) was measured with the Kinder Lydenberg Domini (KLD) index while firm performance the dependent variables was measured with Tobin's q, and testing their relationship with regression analysis method, the study found a mixed relationship between corporate social responsibility and firm performance. Breaking down this mixed findings, the result showed that there is a positive relationship between operational related dimensions of corporate social responsibility and firm performance, and a negative relationship between non- operational dimensions of corporate social responsibility and firm performance. However, in this study, the dimensions of corporate social responsibility were not treated as a unified body thereby making it not possible for all the possible dimensions of corporate social responsibility to have been considered. The breaking of the dimensions of corporate social responsibility into operational and non-operational elements could have been the major factor that drives this finding to be mixed, otherwise a different finding could have been possible should these dimensions of corporate social responsibility have been treated together and not separated into operational and nonoperational. Furthermore, this study was carried out only in the airline industry and as such, made the study to lack the potency of its findings to be generalized. Also, a data set of 1991-2009 (that is a nine years' study period) will account for unprecedented errors which must have contributed to the findings, in which different result could have emerged with a smaller data-set and if similar study was carried out in a different research context. In another study, [33] carried out study in Nigeria on 13 Banks to discover the relationship between corporate social responsibility activities disclosure and commercial banks performance, with data-set of 2009. The researchers measured the independent variable corporate social responsibility through its elements (environment, Human resource, product quality and community involvement) and the dependent variable (firm performance) with: total assets (TA), gross earnings (GE), and number of branches (NB). While regression analysis model was used to determine the extent of relationship and the study revealed a mixed relationship between corporate social responsibility (CSR) and firm performance (FP). The analysis of the findings showed that total assets has positive relationship and statistically significant with the level of corporate social responsibility activity disclosure, while gross earnings and number of branches, though have positive relationship with corporate social responsibility disclosure, nevertheless, they are not significant statistically. However, this study was carried out only in one sector (the banking sector) which is not a representation of the sectors of the economy.

In Nigeria between 2008-2010, [34], carried out study on twenty listed companies of Nigeria stock exchange to examine the relationship between corporate social responsibility (CSR) and firm performance (FP). Measuring the independent variable- corporate social responsibility (CSR) through its elements (Health, education and community) and the dependent variable- firm performance (FP) through accounting indicator- profit after tax (PAT). The 
researchers used multiple regression analysis (MRA) to determine the level of relationship between corporate social responsibility (CSR) and firm performance (FP). The finding showed a mix relationship between corporate social responsibility (CSR) and firm performance (FP). This mixed finding was further analyzed as follows: That education and health as elements of corporate social responsibility, have positive relationship with firm performance, while community has negative relationship with firm performance. That is, concern for education and health resulted to positive increase in the performance of the company and on the other hand, concern for community results to negative impact on firm performance. While the researchers employed a sophisticated statistical tool (multiple regression analysis), however, the measure of the independent variable (corporate social responsibility) were more of the Non-operational elements of corporate social responsibility and ignoring the operational elements of corporate social responsibility (CSR). Assuming more emphasis was given to the operational elements of corporate social responsibility (CSR), the result could have been affected. Furthermore, profit after tax (PAT) is an accounting indicator and as such subject to managerial manipulation. It is essential to also note that profit after tax is a profit generated after considering interest payment to loan creditors and as such, tax deductible variable (interest payment), is an essential mechanism through which management manipulate accounting information especially in nations where there is lack of standards and legislation to ensure fairness and adherence, since interest payment reduces the amount of tax to be paid. Finally, the study failed to depict its population from which the sample size was drawn and as such can't ascertain if the sample size actually represents the population. Following up these literature reviews clearly depict that none of these studies were carried for the purpose of literature review, thereby assembling literatures. Hence there is need for studies to assemble different literature and their findings, thereby contributing to knowledge and bridging gap in study.

\subsection{Corporate Social Responsibility and Firm Performance with Modest Relationship}

Trang T. N. H et al [35] carried out study on 20 largest financial firms in Vietnamese extracted from the two stock exchanges (Ha Noi and Ho Chi Minh) between 2010-2012 to explore the relationship between corporate social responsibility (CSR) and firm performance (FP). Using content analysis to extract information from the company's annual report, the dependent variable (firm performance) was measured through: return on assets (ROA); return on equity (ROE) and return on sales (ROS), while the independent variable (corporate social responsibility) was measured through its dimensions: environment; energy; product combination and customer relation; community; human resource and others. The relationship between the variablescorporate social responsibility (CSR) and firm performance (FP) was explored using multiple regression analysis and the result showed a modest relationship between corporate social responsibility (CSR) and firm performance (FP). However, this is the only study whose result showed modest relationship and as such there is need for further studies.

The above review of past literatures showed that the findings are mixed, only few studies were carried out recently, which suggest gap in literature and require further studies.

Though there are few studies on the individual elements of corporate social responsibility, it becomes necessary to also view it through some of its elements.

\section{Conclusion}

The concept of corporate social responsibility and firm performance has attracted huge interest in the past few decades among researchers. This could partly be that the survival of any firm, it largely associated with her corporate social responsibility. As stated by [36], when firms embark on corporate social responsibility, the firm will enjoy high level of productivity and survival. However, the growing gap in research with respect to some of the elements also referred to as dimensions [37-39], of corporate social responsibility call for more studies in that direction. The positive impact of CSR can't be overemphasized. As noted by [40], the correlation between CSR and organizational effectiveness is significant. This study reviewed some of the past studies on corporate social responsibility and firm performance, to assemble the trends of results and consequently ascertain gap in study. Specifically, studies should be carried out on suppliers- an element of corporate social responsibility to test the impact of firm's social responsibility to suppliers on their performance.

\section{References}

[1] Banerjee, B. S. (2007) CSR The good the bad and the Ugly Edward Elgar publishing limited glensanda house Montpellier parade Cheltenham uk.

[2] Dahlsrud, A., (2008), How Corporate Social Responsibility is Defined: an Analysis of 37 Definitions, Corporate Social Responsibility, Environmental Management, 15, 1-13.

[3] Comincioni N., Poddi L and Vergalli S. (2012). Does Corporate Social Responsibility Affect the Performance of Firms? Electronic Journals.

[4] Masaka D. (2008). Why Enforcing Corporate Social Responsibility (CSR) is Morally Questionable. EJBO Electronic Journal of Business Ethics and Organization Studies Vol. 13.

[5] Windsor, D. (2001), "The Future of Corporate Social Responsibility", in The International Journal of Organization Studies, 9 (3), 225-256.

[6] Abrams, F. (1951). Management's Responsibilities in a Complex World; Harvard Business Review, 29 (30) 29-34.

[7] European Commission (2001). Green Paper-Promoting a European Framework for Corporate Social Responsibility. Bruxelles: European Commission; COM (2001) 366. 
[8] Licandro D. O., Garcia R. G. A., Alvarado-Peña J. L., Osuna V. A. L and Correa P. (20019). Implementation of the ISO 26000 Guidelines on Active Participation and Community Development. Social Sciences, MDPi 8, 263 (2019).

[9] Blowfield M. and Murray A. (2011). Corporate Social Responsibility, $2^{\text {nd }}$ ed. Oxford university Press.

[10] Huczynski, A. A. and Buchanan, A. D. (2013) Organizational Behaviour. $8^{\text {th }}$ ed. Pearson Education limited Edinburgh Gate United Kingdom.

[11] Kotler, P. and Keller, L. K. (2012) A framework for marketing management. $5^{\text {th }}$ ed. Pearson education limited Edinburgh gate: Harlow England.

[12] Marimuthu, M., Arokiasamy, L., and Ismail, M. (2009) Human Capital Development and its Impact on Firm Performance: Evidence.

[13] Selvarajan, T. T., Ramamoorthy, N., Flood, P. C., Guthrie, J. P., MacCurtain, S., and Liu, W. (2007). The role of human capital philosophy in promoting firm innovativeness and performance: Test of a causal model. International Journal of Human Resource Management, 18 (8), pp. 1456-1470.

[14] Kajola, S. O. (2008). Corporate Governance and Firm Performance: The Case of Nigerian Listed Firms. European Journal of Economics, Finance and Administrative Sciences.

[15] James G. March and Robert I. Sutton (1997). CrossroadsOrganizational Performance as a Dependent Variable. Organization Science 8 (6), 698-706.

[16] Hopkins, T. (2012) Corporate Social Responsibility Hand book: Making CSR and Narrative Reporting Work for Your Business, $3^{\text {rd }}$ ed. ICSA Information and Training Limited London.

[17] Margolis, J. D. and J. P. Walsh: (2003), "Misery loves companies: rethinking social initiatives by business", Administrative Science Quarterly, Vol. 38 No. 3, pp. 268-305.

[18] Vogel, D. J. (2005). 'Is There a Market for Virtue? The Business Case for Corporate Social Responsibility'. California Management Review, 47 (4), pp. 19-45.

[19] Fasanya, O. I. and Onakoya, O. B. A. (2013) Does Corporate Social Responsibility Improve Firm Performance of Nigeria Firms. Evidence from Triangulated Analysis. Pakistan Journal of social sciences 10 (2) pp 92-98.

[20] Orlitzky, M., Schmidt, F. L., \& Rynes, S. L. (2003). Corporate social and financial performance: a meta-analysis. Organization Studies, 24 (3), 403-441.

[21] Uadiale, M. O and Fagbemi, O. T. (2012). Corporate Social Responsibility and Financial Performance in Developing Economies: The Nigerian Experience. Journal of Economics and Sustainable Development 3 (4) pp 44.

[22] Piatti, D. (2014) Italian Mutual Banks: Corporate Social and Financial Performance. European Scientific Journal February 2014 Edition Vol. 10 (4). ISSN: 1857 - 7881.

[23] Mishra and Suar (2010). Mishra, S., \& Suar, D. (2010). Does corporate social responsibility influence firm performance of Indian companies? Journal of Business Ethics, 95 (4), 571-601.

[24] Waddock, S. A., and Graves, S. B. (1997). The corporate social performance-financial performance link. Strategic Management Journal, 18 (4), pp. 303-310.
[25] McGuire, J. B., Sundgren, A. and Schneeweiss, T., (1988) Corporate Social Responsibility and Firm Financial Performance. Academy of Management Journal 31, pp. 854 872.

[26] Alexander J. G. and Buchholz A. R. (1978). Corporate Social Responsibility and Stock Market Performance. The academic Management Journal Vol. 21 (3), 479-486.

[27] McWilliams, A., Siegel, D. and Wright, P., (2006) Corporate Social Responsibility: Strategic Implications. Journal of Management Studies 18, pp. 1-18.

[28] Mwangi, I. C. And Jerotich, J. O. (2013) The Relationship Between Corporate Social Responsibility Practices and Financial Performance Of Firms In The Manufacturing, Construction And Allied Sector Of The Nairobi Securities Exchange. International Journal of Business, Humanities and Technology Vol. 3 No. 2 (2013).

[29] Nkaiwatei, A. O. (2011). Relationship between Social Accounting Practices and Profitability: The case of oil industry in Kenya, Unpublished MBA Thesis, University of Nairobi.

[30] Saeidi, P. S., Sofian, S., Saeidi, P., Saeidi, P. S and Saaeidi, A. S. (2014) How Does Corporate Social Responsibility Contribute To Firm Financial Performance? the Mediating Role of Competitive Advantage, Reputation, and Customer Satisfaction. Journal of Business Research 68 (2015), pp. 341350 .

[31] Lean, H. H. and Chang, Y (2011) Corporate social responsibilities and stock returns: Stochastic dominance approach. African Journal of Business Management Vol. 5 (4), pp. 1277-1285.

[32] Lee S., Seo K., \& Sharma A. (2013). Corporate social responsibility and firm performance in the airline industry: The moderating role of oil prices. Tourism Management 38 (2013): 20-30.

[33] Akano, Y. A., Jamiu O. O., Olaniran, Y. A. and Oluwalogbon, T. O. (2013) Corporate Social Responsibility Activities Disclosure by Commercial Banks in Nigeria. European Journal of Business and Management Vol. 5 (7), 2222-2839.

[34] Okafor, C. and Oshodin, E. (2012) Corporate Social Responsibility and Corporate Performance in Nigeria. Journal of Management and Corporate Governance, Vol. 4 (2012) pp. 23-31.

[35] Trang T. N. H and Liafisu Sina Yekini S. L. (2014) Investigating the link between CSR and Financial performance - Evidence from Vietnamese listed companies. British Journal of Arts and Social Sciences, Vol. 17 (I).

[36] Obijuru E. U., Odimegwu B. I., and Kifordu A. A. (2017). Effect of Corporate Social Responsibility and Business Ethics on Organizational Performance of the Petroleum Industry in South-South, Nigeria. University of Port Harcourt Journals of Management, 2 (1): 110-126.

[37] Dahlsrud, A. (2006) How Corporate Social Responsibility is Defined: an Analysis of 37 Definitions, Corporate Social Responsibility and Environmental Management, 15, pp. 113

[38] Hopkins, M. (1998). The Planetary Bargain: Corporate Social Responsibility Comes of Age., Macmillan, London. 
[39] Khoury, George, Janet Rostami, and Lynn Peri Turnbull. 1999. Corporate Social Responsibility: Turning Words into Action. Ottawa: Conference Board of Canada.
[40] Ukpabi, D. C., Ikaba, Y. V., Enyindah, C. W., Orji, O. G., and Idatoru, A. R., (2014). Impact of Corporate Social Responsibility on Organizational effectiveness. Journals of Business and Management, 16 (12): 32-36. 